\title{
MY BODY NOT MY OWN: AN INTERSECTIONAL VIEW ON RELATIONALITY IN FICTION BY TONI MORRISON AND LOUISE ERDRICH ${ }^{1}$
}

\author{
SiLVIa MarTíneZ-FaLQuina \\ Universidad de Zaragoza
}

\begin{abstract}
This essay makes a contribution to the contemporary struggle against gender violence with an analysis of Toni Morrison's Home (2012) and Louise Erdrich's The Round House (2012). The article presents a transethnic comparison combined with an intersectional feminist motivation to highlight the complicity of racism and sexism, and it articulates a theorization of relationality as the way to counter the dissociation derived from violence. Arguing for the pivotal role of the women of color whose bodies are violated - sterilized, raped - in the texts, it offers a close reading of the indirect account of violence, the conflicted male characters, ambivalent symbols and open endings, and the connection to African American and Ojibwe myth. The article leads to the conclusion that relationality is the best response to the systemic violence of the coloniality of gender.
\end{abstract}

KEY WORDS: women of color, racist/sexist violence, transethnic approach, intersectionality, relationality.

Mi cuerpo no es mío: una visión interseccional a la relacionalidad en obras de Toni Morrison y Louise Erdrich

Este artículo contribuye a la lucha actual contra la violencia de género con un análisis de Home (2012), de Toni Morrison, y The Round House (2012), de Louise Erdrich. El artículo presenta una comparación transétnica combinada con una motivación feminista interseccional que resalta la complicidad del racismo y el sexismo, y articula una teorización de la relacionalidad dirigida a contrarrestar la disociación derivada de la violencia. Defendiendo la centralidad de las mujeres de color cuyos cuerpos son transgredidos - esterilizados, violados- en los textos, ofrece una lectura atenta de la representación indirecta de la violencia, los personajes masculinos en conflicto, símbolos ambivalentes y finales abiertos, además de la conexión con mitos afro-americanos y ojibwe. El artículo concluye que la relacionalidad es la mejor respuesta frente a la violencia sistémica de la colonialidad del género.

PALABRAS CLAVE: mujeres de color, violencia sexista/racista, aproximación transétnica, interseccionalidad, relacionalidad.

\footnotetext{
${ }^{1}$ The research carried out for the writing of this article is part of a project financed by the Spanish Ministry of Economy, Industry and Competitiveness (MINECO) in collaboration with the European Regional Development Fund (DGI/ERDF) (FFI2017-84258-P). The author is also thankful for the support of the Government of Aragón and the European Social Fund (ESF) (H03_17R).
}

Martínez-Falquina, Silvia (2020), "My Body Not My Own: An Intersectional View on Relationality in Fiction by Toni Morrison and Louise Erdrich", Lectora, 26: 117-132. ISSN: 1136-5781 D.O.I.: 10.1344/Lectora2020.26.8, smfalqui@unizar.es

Recepció: 15 de desembre de 2019 - Acceptació: 31 de març de 2020 


\section{Word warriors against the culture of silence}

Even the most cursory look at the world around us evidences the persistence of violence against women, the violation of human rights which affects the largest number of people, and which is outrageously frequent amongst women of color. Engaging with this reality in literature, in the year 2012, Toni Morrison and Louise Erdrich each published a novel centered on a white man's traumatic violation of an ethnic woman's body. Morrison's Home follows black Korean veteran Frank Money's return to Lotus, Georgia, to save his sister Cee, the victim of a eugenicist white doctor who sterilizes her and leaves her at the brink of death. Erdrich's The Round House, set on an Ojibwe reservation in North Dakota in the late 1980s, denounces the failure of justice for Native rape victims like Geraldine Coutts at the hands of white men. Although this is by no means the first time that these authors represent crimes against women, the urgency with which they denounce sexist and racist violence in these novels deserves more attention than it has so far been given.

Making the most of their position as well-established writers, Morrison and Erdrich resist the culture of silence about sexual assault associated to repression or shame and instead continue the long-standing tradition of women of color who "described and denounced their sexual misuse, deploying their voices as weapons in the wars against white supremacy" (McGuire, 2004: 907). Natalie Clark highlights how "word warriors" - a term she uses to characterize from young girls in therapy to established Native writers - have been speaking about "violence at the intersections of Indigeneity, gender, age and geography since colonization began" (2016: 2). She claims that the act of telling in certain spaces and relationships "facilitates and allows for relational witnessing and accountability" (3), for "as listeners or receivers of [these] stories, we are witnesses and essential partners" in the resistance of women (10).

Morrison and Erdrich are word warriors who create such fictional spaces of relational witnessing and accountability in their texts. In order to include the largest possible number of readers, they offer more linear and realistic narratives than usual. ${ }^{2}$

\footnotetext{
${ }^{2}$ Reviewers' reactions to Home were especially harsh due to Morrison's choice of brevity and understatement. It was considered "less dazzling", "more incomplete" than Morrison's past works, and the transformation and healing accounted for in the narrative were seen as "all too brief and anticlimactic, lacking the complexity we have come to expect of Morrison" (Akbar, 2012). Similar opinions were expressed by Churchwell (2012), Daniel (2012), Diu (2012) and Ulin (2012). As for The Round House, reviewers noted its departure from Erdrich's usual "assortment of narrators or points of view" (Miller, 2013). Kakutani (2012) stated that the individual narrator approach "deprives the novel of the choral effect of so much of her earlier fiction", although she also admitted that this choice was the source of the book's emotional power. Similarly, Ibarrola-Armendariz, who holds that Erdrich's style is usually more lyrical (2016: 18), notes that the choice of narrator and genre gives the novel "a
}

118

Lectora, 26 (2020): 117-132. ISSN: 1136-5781 D.O.I.: 10.1344/Lectora2020.26.8 
Their contribution to the struggle against gender violence vindicates their respective African American and Native American roots: the protagonists' narratives of grief are validated in their own terms, showing pride in their distinct ways of healing. The novels' narrative specificity demands an active reader to figure out the socio-political context they refer to. But the authors' engagement in a dialogue with the past also evidences how the tentacles of sexism and racism function in unison and are deeply rooted in even the most reputedly democratic socio-cultural structures of today. Hence, a revisiting of both novels in the post \#MeToo context or in the light of the MMIW awareness campaign underscores them as symptomatic of the urgency of mobilization against gender violence that has come to characterize the present time. Both the voicing of specifically African American and Native American vindications and their dialogue with global feminist developments point to a productive relationship of text and context which responds to the activist impulse to make a difference in the world through writing.

This article explores the critical possibilities of a "transethnic" (Simal-González, 2011) approach to sexist violence in Home and The Round House. ${ }^{3}$ Combined with an intersectional feminist motivation, the transethnic comparison offers an assertive and simultaneously revisionist view on ethnic specificities and examines the influence of sexism and racism within and beyond ethnic borders. Individuals like the ones depicted in these novels are attacked as "female embodiments of their socio-cultural identities" (Skjelsbaek, 2001: 223), which determines both the specific consequences of the violations they suffer and their particular way of dealing with their traumas. However, Cee's sterilization and Geraldine's rape are also two different consequences of the same sexist colonial system which perceives women of color as inherently impure and available for the taking. It is only by focusing on the way different women are attacked in similar ways that the complicit tactics of patriarchy and racism can be critically unveiled and challenged.

This perspective, which promotes the development of a productive transethnic solidarity, is inextricably linked to the idea of relationality, a basic pillar of the novels' vindications and an essential feature of the current transmodern era. According to Anishinaabeg critic and writer Leanne Simpson, who theorizes Native resurgence as

momentum that is hard to find in Erdrich's earlier works" (17). Tharp also suggests that Erdrich's compelling "crusade against rape" justifies this change (2014: 25).

${ }^{3}$ My strategic comparison of the representation of gender violence does not allow me to cover the full narrative complexity of each text. Amongst the many articles which deal with Home, I have found Harack and Ibarrola-Armendariz (2017), Onega (2017) and Visser (2014; 2016) particularly illuminating. As for The Round House, Bowers (2017) and Tharp (2014) address the issue of violence against Native women in the novel, while Castor (2018) and Bender \& Maunz-Breese (2018) explore the novel in depth. 
relation, the way to cognitively reverse the violence of colonial dispossession is not by focusing on possession - which she negatively associates to capitalism - but through relation, "a coded layering of intimate interconnection and interdependence that creates an algorithmic network of presence, reciprocity, consent and freedom" (2015). The latest theoretical developments of the transmodern paradigm -a term introduced by the Spanish philosopher Rosa María Rodríguez Magda (2015) and broadly characterized by connectivity, globalization and relationality- seem to move in a similar direction. For example, Irena Ateljevic underscores the "new relational consciousness" that leads us to "re-participate with the body of nature" and "to accept contradicting realities and multicultural perspectives" (2013: 213; emphasis in the original). Other recent developments, like Judith Butler's theorization of interdependency, or the idea that we are all born into "a condition of radical dependency" on social and material structures but also on the environment, "all of which makes life possible" (2018); Christian Moraru's Levinasian emphasis on beingwith and what he calls "an ecology of relations" (2011: 48; emphasis in the original); Jeremy Rifkin's belief that "[t]he Age of Reason is being eclipsed by the Age of Empathy" (2009: 3); or Virginia Held's account for an ethics of care which is "hospitable to the relatedness of persons" (2006: 15), are all hopeful calls to counter persistent inequality and separation by focusing on relation. As shown below, relationality is relevant both intratextually - Home and The Round House articulate relationality as the only possible response to the dissociation brought on by violenceand extratextually - as a strategic approach to the different manifestations of violence against women.

\section{A relational approach to unique traumas}

The 1950s setting of Home is Eisenhower's era of affluence and Cold War anxiety, with references to the Korean war, the House Committee on Un-American Activities (HUAC), and bomb shelters in well-off homes. Examples of blatant racism abound, and main character Frank Money is very aware that the world is not a safe place for those like him, always at risk of being attacked, violated. Nevertheless, the worst part of 1950s discrimination is experienced by black women like his sister Cee, who grows up under the threat of being harassed by white and black men alike, only to end up working for a white doctor who uses her body to experiment on her, leaving her scarred and barren. Evoking the Tuskegee experiments (Bollen, 2012), Cee's sterilization is connected to a centuries-long history of medical abuse on African Americans which statedly makes them the group that most deeply "mistrusts the American medical system, especially medical research" (Washington, 2006: 5). This and numerous other examples of experimentation on and violation of African American bodies prove the racist ideology underlying whitestream science and policy, 
and is directly associated to eugenics, a subtext of racism which is also present in Home.

At the beginning of the novel, Frank makes a hairbreadth escape by leaving the hospital out of which, according to Reverend John Locke, "they sell a lot of bodies" to the medical school, for "doctors need to work on the dead poor so they can help the live rich" (Morrison, 2012: 12). Cee is not that lucky, and when she is offered a job in a beautiful uptown district house in Atlanta, she confronts things her limited education does not allow her to understand. Looking at the doctor's books titles, she "promised herself she would find time to read about and understand 'eugenics.' This was a good, safe place, she knew" (65), the ironic third person narrative voice lets on, distancing itself from the focalizer. Imprisoned by her feelings of inferiority and inadequacy, she will be incapable of preventing Dr. Beauregard - whose wife claims is "no Dr. Frankenstein" (60) - from using her body for experimentation.

The Round House offers a retrospective view on racism against Native Americans in the 1980s. Interaction between the novel's rich cast of Native characters and white outsiders is scarce but confrontational, and racism comes from a despising pregnant woman in hospital, a white girl's Catholic family, as well as from the white rapist. But the focus of Erdrich's denunciation is set on the ease with which hate crimes against Native women can be committed. First person narrator Joe Coutts' mother Geraldine is raped in an area where tribal, private and federal lands meet, which makes it impossible to specify jurisdiction to prosecute the white perpetrator. Besides, the rape of the Indian woman also entails a violation of the Ojibwe sacred ceremonial space of the round house, which Joe's ancestors built "to keep their people together and to ask for mercy from the Creator, since justice was so sketchily applied on earth" (Erdrich, 2012: 315). Soon after the attack, Joe painfully reports his realization that "[s]ome warm part of [his mother] was gone and might not return" (193). Similarly, the "old ceremonial place" (60) unveils to Joe his witnessing of "the part of something larger, an idea, a truth, but just a fragment" (215) of a different, ancient way of life, of the connection of place, tradition and person, at risk under the dissociating forces of colonization.

The rape of Geraldine is one literary example of the widespread problem of sexual violence against indigenous women in the United States, which has been rising on Indian reservations for several decades (Cook-Lynn, 2012: 96), as denounced by Amnesty International in a broadly distributed report (2007). ${ }^{4}$ Despite the progress

\footnotetext{
${ }^{4}$ See Owens (2012) and Tharp (2014) for a useful coverage of the legal developments on this issue. In spite of the situation, Sarah Deer questions the adequacy of the word "epidemic" to refer to the rape of Native American women. For her, "rape is a fundamental result of colonialism, a history of violence reaching back centuries. An epidemic is a contagious disease; rape is a crime against humanity” $(2015, \mathrm{x})$.
} 
made by the Obama administration, as Erdrich reminds us in her afterword, "the tangle of laws that hinder prosecution of rape cases on many reservations still exists" (Erdrich, 2012: 319). Violence is so generalized that Native women find themselves "in the role of prey, to a predator society, whether for sexual discrimination, exploitation, sterilization, absence of control over our own bodies, or being the subjects of repressive laws and legislation in which we have no voice" (LaDuke, 2002: 213).

A transethnic comparison of these texts shows that the violations of Cee and Geraldine are both specific to their respective African American and Native American contexts and representative of violence against women of color at large: they are raped, sterilized, dispossessed of their bodies all too frequently. Racism and sexual violence work together as tactics that sustain the processes of colonization. Hence, an intersectional approach is required to address race and gender jointly, for "the logic of categorical separation distorts what exists at the intersection, such as violence against women of color" (Lugones, 2008: 4). Lugones' theorization of the coloniality of gender unmasks the complicit collaboration of the colonial and gender structuring systems, and "[i]t is only when we perceive gender and race as intermeshed or fused that we actually see women of color" (4). The human/non-human dichotomy established by colonial logic conceives the subaltern as instruments for the benefit of the white colonists, and because this system is intimately linked to sexuality, the bodies of women of color were constructed as available for the taking (Lugones, 2012). The resulting objectification of women of color - who threaten white privilege in their ability to reproduce the next generation of peoples who could resist colonization, and could also pose a threat to patriarchal ownership of white women by showing alternative ways of structuring gender relations (Smith, 2003: 76-77) - makes their bodies not their own, symbolically and literally. The images of degraded, sexualized and demonized blacks and Natives that the colonial agenda promoted also contributed to hindering relations between white women and women of color. All in all, the system functions as a tool to maintain colonial preeminence of whites over ethnic minorities, and as a weapon of patriarchal control which affects not only women of color, but all women.

The awareness of the motivations behind violence against women of color confirms the essential dysfunctionality of the whole social structure where it so commonly appears, and this recognition is the first step for real transformation. Clear knowledge of the logic of oppression opens a door for resistance, and as exemplified in these texts, the answer to colonial dispossession lies, above all, in relation.

\section{Recovering the center: From victims to healers}

According to Régine Jean-Charles, when trying to represent sexual violence artists face the risk of objectifying and re-victimizing the subject, and of normalizing 
a horrific reality by the creative use of violence (2009: 250). Artists should, therefore, protect and restore subjectivity, expose and contextualize the realities of rape, and "create possibilities of subjectivity despite rape" (250). Especially useful is what she calls "an aesthetic of multiplicity", which "manages to reveal an embodied female subject beneath layers of violence" (257). Jenny Edkins similarly refers to the problem of depoliticizing trauma when it is re-inscribed in a linear narrative, and she claims that authors should keep open a "space for genuine political challenge by encircling the trauma rather than attempting to gentrify it" (2003: 15). As I will argue, in Home and The Round House the subjectivity of the victims is strategically restored by means of an aesthetic of multiplicity and encircling, broadly understood as indirection. The violations of Cee and Geraldine entail an attack on their gender and racial identity, and recognizing their communal identification - which emphasizes the preeminence of specific cultural definitions - is the only effective response to that attack.

Interestingly, the actual attacks - the experimentation on Cee's body and the rape and attempted murder of Geraldine- take place off-scene, and they are presented in retrospect as filtered or partial memories. Further pointing to the strategic indirect representation of trauma, both novels deal with the violation of a woman from the perspective of the masculine caretaker or protector who is also affected by the women's experience. The texts depict the traumatic experience of the male characters as one of overwhelming disconnection, which ignites the search for reconnection to self, community, and place in order to heal, and in both cases, the healing of the masculine self will be determined by the healing of the violated woman. Although previous studies of the novels have largely missed the central place that the women occupy in them, it is only by acknowledging these characters' pivotal position in the structural and thematic development of the narratives that we can apprehend the full extent of what Morrison and Erdrich are suggesting: the idea of relationality as the way to counter the dissociation and displacement resulting from violence.

In Home, Cee's whole family knows exactly what displacement means: they are always at risk of being expelled, as when they were cruelly evicted from their house by a lynching mob in Texas in the 1930s, or when Frank is subject to invasive control on the street. The daughter of an absent mother working two jobs, bullied by a wicked step-grandmother and with no chance of receiving an education, Cee is vulnerable to the attacks of white and black men: the flasher who approaches her while she is playing, the husband who uses her to steal a car, or the evil doctor who experiments on her body. Apart from the description of her pain when learning that she will not be able to be a mother, Cee's trauma is not developed in the narrative. Instead, we are offered lengthy detail of the PTSD symptoms which accompany Frank's journey after the war: his anxiety, his visions of the battlefield, of body parts, of his dead buddies.

Geraldine's life on the reservation before her attack is depicted through the nostalgic perspective of The Round House's adult narrator, who emphasizes the 
impact of the disruption by setting the stability of the Coutts in contrast to surrounding cases of violent or broken families. The rapist's racist, misogynist words about Native women addressed to Geraldine and Mayla — the Native girl he kills and whose body is never found- and the whole lack of protection of women on the reservation evidence Native women as prey in the hands of white men. After her rape and attempted murder, Geraldine's spirit is severed from her body (Erdrich, 2012: 45); she isolates herself from her family and friends, she acquires a "spidery look" (87) and can simply not come back to life (88). Her son Joe is the focalizer who retrospectively translates to the readers her grief and how it has affected them and their community, whose center is also violated.

In spite of the texts' differences in development and resolution, they both emphasize the way healing is directly associated to solidarity, community and tradition. In Home, as soon as Frank frees Cee from the evil doctor, he puts her in the care of the healers in Lotus. Those women - "who loved mean”, and handle sickness "as though it were an affront, an invading braggart who needed whipping" (Morrison, 2012: 121) - take control and use unconventional remedies to make Cee physically and psychologically healthy again. The Round House centers on the need for justice prior to any possible healing. When Joe realizes that no matter how hard he and his tribal judge father try to find justice in US laws, and that these laws are part of the problem and not the solution, Joe becomes, in his words, "dedicated to a purpose which I'd named in my mind not vengeance but justice” (Erdrich, 2012: 260). The most obvious transformation for Joe derives from the need to change codes, adopting the beliefs and ways of procedure of his old Anishinaabe inheritance in the traditional stories told by elder Mooshum about Nanapush, Old Buffalo woman and the wiindigo.

In the face of such attacks, Frank and Joe present themselves as saviors of women. Frank rescues Cee from the doctor's claws and puts her in safe hands, and Joe kills his mother's attacker - with the help of his friend Cappy - once he realizes that regular justice will not keep him in jail. Despite their intention to help the women, Frank and Joe's part as heroes is complicated for several reasons. The first is the way their defining role is questioned in the novels, for the women resist being defined by them. In Home, the most important lesson Miss Ethel transmits to Cee is that she should define herself and be free: "Look to yourself. You free. [...] Don't let Lenore or some trifling boyfriend and certainly no devil doctor decide who you are. That's slavery" (129). Cee's vindication of her own self-definition invalidates any other person's attempts at telling her story in full, and this includes the narrator and Frank. As for Geraldine, her job "was to know everybody's secrets", and she "kept her files locked in a safe. No one else knew the combination of the safe" (149). Because she decides which information about the crime she shares, Joe never achieves complete or certain knowledge about what happened, and the novel thus reflects on the difficulty of telling 
somebody else's story. Not only do the textual implications call into question the defining roles of the two narrators, but the texts also make a point of the fact that it is the women who define the men instead, if not actively, at least by reflecting the men's idea of themselves. In Home, Frank admits that Cee was the first person he took responsibility for, and, as he says, "Down deep inside her lived my secret picture of myself" (104; italics in the original). In The Round House, Joe and his father feel at a loss when Geraldine disappears, and Joe's reflection on her absence evidences her as the center of their lives: "Women don't realize how much store men set on the regularity of their habits. We absorb their comings and goings into our bodies, their rhythms into our bones. Our pulse is set to theirs" (3). The two women thus act as the referents where Frank and Joe look for self-definition, whose identities only make sense in relation to the former.

The second heroic trait that is challenged is the male characters' self-assigned role as protectors. Cee decides after she is healed that "she wanted to be the person who would never again need rescue" (Morrison, 2012: 129), and this leaves Frank, who had defined himself as her savior since early childhood, compelled to figure out the kind of man he wants to be. In turn, Geraldine explicitly asks Joe to stop trying to solve the crime: "You will not be part of this" (Erdrich, 2012: 90), she tells him. Although his parents try to alleviate his haunting sense of guilt by interpreting his act as "[t]raditional precedent [which] fulfilled the requirements of a very old law" (306), and as "a wrong thing which serves an ideal justice" (306), Joe's disobedience adds to the family's sorrow with a burden that all three will have to carry for life.

By complicating Frank and Joe's defining and savior role, the texts call attention to the emasculation of the African American and Native American man in a racist and sexist context. Frank comes back alive from the war only to find himself in a situation of extreme vulnerability in the segregated United States of the 1950s, where any white man might decide to attack him with impunity. Joe is still young and experimenting the birth of his sexuality, but he witnesses how his father Bazil is rendered powerless, incapable of acting in the search for justice even from his relatively privileged position as a tribal judge. Neither Frank nor Joe or Bazil can live up to the images of strong, proactive masculinity associated to their respective cultures.

Last but not least, Frank and Joe's heroic roles are complicated by the narrative questioning of their moral integrity, for even if they define themselves as protectors of sister and mother, they are also perpetrators of a crime against other women. During the war, as he admits to himself in the end with the help of Cee, Frank killed a Korean girl who sexually tempted him, arguing: "How could I let her live after she took me down to a place I didn't know was in me?" (Morrison, 2012: 134; italics in the original). His transformation throughout the novel consists of the direct admission of his crime, which he had hidden to himself by proudly grieving over his 
dead friends: "My mourning was so thick it completely covered my shame" (133; italics in the original). Although killing that poor Korean girl is the most terrible crime Frank commits, the way he defines his attraction to the two regular girlfriends he had reveals much about his "perverse sense of masculinist power and privilege" (Montgomery, 2015: 19):

I liked the small breakable thing inside each one. Whatever their personality, smarts, or looks, something soft lay inside each. Like a bird's breastbone, shaped and chosen to wish on. A little $V$, thinner than bone and lightly hinged, that I could break with a forefinger if I wanted to, but never did. Want to, I mean. Knowing it was there, hiding from me, was enough. (Morrison, 2012: 67-68; italics in the original)

Frank's masculinity is marked as a threat to women on at least two other occasions: while Miss Ethel and the other women are nursing Cee, they block Frank from visiting her because "they believed his maleness would worsen her condition" (119). The garden that Miss Ethel shields from "the whole predatory world" (130) which threatens it may not be Eden, but it functions as an illustrative symbol of how femininity sometimes needs to be fiercely protected as well as nurtured. There is also an uncomfortable moment in Portland when Reverend Jessie Martland, who helps Frank to get back to Lotus, does not invite him beyond his porch, saying, by way of apology, that his daughters are inside the house. To Frank, "[i]t was an insult tax levied on the supplicant for an overcoat, sweater and two ten-dollar bills" (22). Men are perceived as a potential threat to women, which explains that the boys' fathers and mothers of Lotus do not object to the sexual relations offered them by a local widow, because " $t$ ] eenagers had to learn somewhere [...]. Besides, their own daughters were safer that way" (90).

Apart from taking justice in his own hands, Joe's ambivalent relationship to women and sex makes him yet another kind of perpetrator. If the sexism prevalent in society is responsible for his mother's rape, it also explains Joe's attitude to his aunt Sonja, an ex-stripper he is sexually attracted to. When he insists on participating in a strip dance she was offering ancient Mooshum as a birthday gift, Joe objectifies and threatens her. As an adult, Joe regrets his betrayal and ponders that "all [his] life - [he] wanted to be something better" (Erdrich, 2012: 223). In the end, Joe chooses his father's imperfect and relatively impotent model, and he takes over Bazil's search for justice as a tribal judge.

Through indirection and the narrative complexity derived from the ambivalence of the novels' main characters and their partial narrative visions, the authors guide readers back to the women for ethical referents. Far from being passive victims, Cee and Geraldine act as agents at the center of their respective narratives: not only do 
they guide Frank and Joe in their respective - albeit incomplete - transformations, but they also take the reins of their own healing processes, becoming powerful women who face suffering by re-making themselves. This and the third person account of their experience connect them to myth, a way to reinforce womanhood in response to the attacks of sexism and racism.

The final stage of Cee's healing by the women of Lotus is a good example of this mythic connection: "She was to be sun-smacked, which meant spending at least one hour a day with her legs spread open to the blazing sun. Each woman agreed that that embrace would rid her of any remaining womb sickness" (Morrison, 2012: 124). Cee receives "the sun's violent rays" (124), and through this symbolic impregnation by the sun, she will become a healthier, more confident human being, with a place in the female African American community of Lotus. Erdrich's novel refers to myth through the traditional Ojibwe stories that ancient Mooshum mutters in his sleep for Joe to hear. When, in times of scarcity and starvation, Akiikwe/Earth Woman is accused of being a wiindigoo or evil monster, her twelve-year-old son Nanapush saves her. His spiritual helper Old Buffalo Woman teaches Nanapush how to survive "by doing the opposite of all others" (214), and she instructs him on how to build the round house, which "will be the body of your mother and it must be respected the same way" (214215). Geraldine is attacked in this mythical place, which connects her to traditional Ojibwe stories, powerful songs and sacred mothers. Like the round house, she is hurt but surviving.

The creative power that Cee and Geraldine possess, sustained on the women's ability to reconnect with themselves and their community, is made manifest in their remaking of themselves and of the men by their sides. This is particularly relevant in the novels' articulation of healing as requiring a reinforcement or renewal of relation. Cee and Geraldine respectively express their reconnecting creativity through quilting and gardening. Cee will not be able to fulfill her yearned-for mother role, but while making her quilt, "which symbolises her piecing together of her own identity and selfesteem" (Harack and Ibarrola-Armendariz, 2017: 294), she relates to the women in her community and acquires a renewed sense of purpose. As for Geraldine, once her rapist is dead, she can take care of her garden again, and she is reconnected to the traditional stories and the land, reinforcing her sense of herself as an Ojibwe. Healing is not complete in this case either, and the end of the novel shows us a family who, while resilient, carries the scars of their traumatic experience and whose sentence is "to endure" (Erdrich, 2012: 317).

The processes of healing through reconnection that Cee and Geraldine each lead facilitate the necessary rituals of transformation that determine Frank's and Joe's coming-of-age narratives, both of which are presented as a sort of public confession aimed at recovery through storytelling. The novels problematize conventional models of masculinity, offering a new concept of manhood defined in relation to women and 
community which challenges persisting stereotypes of black and Native men. In both cases, the healing of the self and the healing of the other are inextricably linked, thus proposing an ethics of care. Progressively refusing to resort to violence as a response to his inherited shame - derived from his emasculation as a black man- Frank symbolically buries his past self in the final ceremony for the black man whose improper burial he witnessed as a child. Joe learns how to be a contemporary traditional Native American man who acknowledges cultural hybridity but resists uprootedness by choosing the Ojibwe protector model of Nanapush. In sum, by coming to terms with the violation of sister and mother, Frank and Joe finally decide that the kind of man they aspire to be must be caring, respectful and giving, as opposed to violent, objectifying and self-oriented. Morrison and Erdrich represent sexual violence as an ill that affects society in full. They also take the opportunity to challenge stereotypical behavior, re-examine gender relations, and place women at the center of a web of support that will lead to the end of violence.

\section{Split down the middle... We just kept going: Ambivalent symbols and unfinished endings}

Expectedly, the rebuilding of these traumatized selves cannot be presented as a happy ending or a restoration of some ideal situation previous to the attack, and the novels articulate healing as an ongoing process instead. In comparison to other works by Morrison, Home offers "a remarkably positive closure" (Visser, 2016: 161) when, using Cee's handmade quilt, a symbol of the proactive and creative reconnection of her self, Frank puts the black man's remains at the base of the sweet bay tree, which is "split down the middle, beheaded, undead - spreading its arms, one to the right, one to the left" (Morrison, 2012: 144). The tree, like Frank and Cee, "looked so strong/ So beautiful./ Hurt right down the middle/ But alive and well" (147), a symbolic sign of resilience in spite of persisting wounds. The Round House ends on a more tragic note: after Joe's best friend Cappy dies in a car accident, the narrator reports, "my mother and father walked in the door disguised as old people. [...] I'd gotten old along with them. I was broken and fragile" (Erdrich, 2012: 317). This final scene laments the abrupt loss of childhood: with Joe riding in the front of the car, his mother in the back seat, the family drive past a place of childhood memory. The closing words point not to closure, but to Joe's unstoppable transition to the cruel, ambivalent world of adults: "we did not stop this time. [...] We passed over in a sweep of sorrow that would persist into our small forever. We just kept going” (317).

The novels' open endings and ambivalent symbols - the tree, broken and alive; the old age in youth - together with relevant narrative choices like the indirect account of trauma, the contradictions of the male protagonists or the mythic characterization of the women all motivate a reflection about shared responsibility in the social structure which supports crimes like those described in the novels. Through

128

Lectora, 26 (2020): 117-132. ISSN: 1136-5781 D.O.I.: 10.1344/Lectora2020.26.8 
the acute and perceptive characterizations of Cee and Geraldine - examples of the humanization and individuation of victims necessary to avoid objectification and revictimization - the authors involve readers in the consequences of sexist and racist crimes. The texts call attention to how violence is aimed at inflicting pain to individual women but also at shaming and emasculating men, and at disrupting full communities. The novels thus resist persisting patterns of silence and invisibility to raise awareness about racist and sexist violence, but they also go beyond traumatic dissociation by emphasizing resilience and restoration.

Moreover, by representing the attacks on women of color and their communities as breaking up the relations with body, self, family, community and place in order to control colonized peoples, it becomes evident that the healing from and resistance to violence will require a reconsideration and rebuilding of such relations. A transethnic approach should never obviate the cultural particularities of violence against African American and Native American women, just as the reinterpretation of being as being-with should not suggest the absence of conflict or the blurring of power inequalities. But by making visible the connections between these groups and the intersections of patriarchy and racism, we can focus on the restoring possibilities of relationality in the struggle against the systemic violence that affects all women.

\section{WORKS CITED}

Akbar, Arifa (2012), “Home, by Toni Morrison”, The Independent, 20/04/2012. $<$ http://www.independent.co.uk/arts-entertainment/books/reviews/home-bytoni-morrison-7660995.html>

Amnesty International (2007), Maze of Injustice: The Failure to Protect Indigenous Women from Sexual Violence in the USA, New York, Amnesty International Publications. <https://www.amnestyusa.org/reports/maze-of-injustice/>

Ateljevic, Irena (2013), "Visions of Transmodernity: A New Renaissance of Our Human History?”, Integral Review, 9 (2): 200-219.

Bender, Jacob and Lydia Maunz-Breese Bender (2018), "Louise Erdrich's The Round House, the Wiindigoo, and Star Trek: The Next Generation", American Indian Quarterly, 42 (2): 141-161.

Bollen, Christopher (2012), “Toni Morrison”, Interview Magazine, 01/05/2012. $<$ http://www.interviewmagazine.com/culture/toni-morrison>

Bowers, Maggie Anne (2017), "Literary Activism and Violence against Native North American Women: The Urgency for Sovereignty”, Wasafiri, 32 (2): 48-53.

Butler, Judith (2018), "Ethics and Politics of Non-Violence", Centre de Cultura Contemporània de Barcelona, 17/04/2018. <http://www.cccb.org/ca/multi media/videos/letica-i-la-politica-de-la-no-violencia/228942> 
Castor, Laura (2018), “Louise Erdrich's The Round House: Restorative Justice in a Coming of Age Thriller", Nordlit, 40: 31-49.

Churchwell, Sarah (2012), "Home by Toni Morrison Review", The Guardian, 27/04/2012. <http://www.theguardian.com/books/2012/apr/27/toni-morrisonsarah-churchwell-home>

Clark, Natalie (2016), "Shock and Awe: Trauma as the New Colonial Frontier", Humanities, 5 (1) 14: 169-188.

Cook-Lynn, Elizabeth (2012), A Separate Country: Postcoloniality and American Indian Nations, Lubbock, Texas Tech UP.

Daniel, Lucy (2012), "Home by Toni Morrison: Review”, Telegraph, 24/05/2012. $<$ http://www.telegraph.co.uk/culture/books/bookreviews/9272768/Home-byToni-Morrison-review.html>

Deer, Sarah (2015), The Beginning and End of Rape: Confronting Sexual Violence in Native America, Minneapolis, University of Minnesota Press.

Diu, Nisha Lilia (2012), "Home by Toni Morrison: Review", Telegraph, 10/05/2012. $<$ http://www.telegraph.co.uk/culture/books/fictionreviews/9246047/Home-byToni-Morrison-review.html>

Edkins, Jenny (2003), Trauma and the Memory of Politics, Cambridge, Cambridge UP.

Erdrich, Louise (2012), The Round House, New York, HarperCollins.

Harack, Katrina and Aitor Ibarrola-Armendariz (2017), "Trauma, Screen Memories, Safe Spaces and Productive Melancholia in Toni Morrison's Home", Traumatic Memory and the Ethical, Political and Transhistorical Functions of Literature, Susana Onega, Constanza del Río and Maite Escudero (eds.), London, Palgrave Macmillan: 279-310.

Held, Virginia (2006), The Ethics of Care: Personal, Political, and Global, Oxford, Oxford UP.

Ibarrola-Armendariz, Aitor (2016), “Genre Reconsidered in Louise Erdrich's The Round House", Revista de estudios norteamericanos, 20: 13-37.

Jean-Charles, Régine Michelle (2009), "Beneath the Layers of Violence: Representations of Rape and the Rwandan Genocide", Local Violence, Global Media: Feminist Analyses of Gendered Representations, Lisa M. Cuklanz and Sujata Moorti (eds.), New York, Peter Lang: 246-266.

Kakutani, Michiko (2012), "Ambushed on the Road to Manhood: The Round House: Louise Erdrich's New Novel”, The New York Times, 15/10/2012. $<$ http://www.nytimes.com/2012/10/16/books/the-round-house-louise-erdrichsnew-novel.html? mtrref=www.google.com\&gwh=546B74813A63FB631D08673 CBF4 8859A\&gwt=pay> 
LaDuke, Winona (2002), The Winona LaDuke Reader: A Collection of Essential Writings, Stillwater, Voyageur Press.

Lugones, María (2008), “The Coloniality of Gender”, Worlds \& Knowledges Otherwise, 2 (2), "On the De-Colonial (II): Gender and Decoloniality": 1-17. $<$ https://globalstudies.trinity.duke.edu/projects/wko-gender>

—(2012), "Subjetividad esclava, colonialidad de género, marginalidad y opresiones múltiples”, Pensando los feminismos en Bolivia, Serie Foros 2, Patricia Montes (ed.), La Paz, Conexión Fondo de Emancipación: 129-140.

McGuire, Danielle L. (2004), “It Was like All of Us Had Been Raped!': Sexual Violence, Community Mobilization, and the African American Freedom Struggle", The Journal of American History, 91 (3): 906-931.

Miller, Laura (2013), “The Round House by Louise Erdrich: Review”, The Guardian, 18/05/2013. <http://www.theguardian.com/books/2013/may/18/round-houselouise-erdrich-review $>$

Montgomery, Maxine (2015), "Bearing Witness to Forgotten Wounds: Toni Morrison's Home and the Spectral Presence", The South Carolina Review, 47 (2): 14-24.

Moraru, Christian (2011), Cosmodernism: American Narrative, Late Globalization, and the New Cultural Imaginary, Ann Arbor, University of Michigan Press.

Morrison, Toni (2012), Home, New York, Vintage.

Onega, Susana (2017), "Narrative Form, Memory Frictions and the Revelation of Traumatic Secrets in Toni Morrison's Home", Memory Frictions in Contemporary Literature, María Jesús Martínez-Alfaro and Silvia Pellicer-Ortín (eds.), London, Palgrave Macmillan: 41-63.

Owens, Jasmine (2012), “'Historic' in a Bad Way: How the Tribal Law and Order Act Continues the American Tradition of Providing Inadequate Protection to American Indian and Alaska Native Rape Victims", Journal of Criminal Law and Criminology, 102 (2): 497-524.

Rifkin, Jeremy (2009), The Empathic Civilization: The Race to Global Consciousness in a World in Crisis, New York, Jeremy P. Tarcher/Penguin.

Rodríguez Magda, Rosa María (2015), Transmodernidad, Barcelona, Anthropos.

Simal-González, Begoña (2011), “The Challenge of Going Transethnic: Exploring American Autobiography in the Twenty-First Century", Revista de estudios norteamericanos, 15: 33-49.

Simpson, Leanne (2015), "The Misery of Settler Colonialism: Roundtable on Glen Coulthard's Red Skin, White Masks and Audra Simpson's Mohawk Interruptus", presented at the Annual Meeting of the American Studies Association, $08 / 10 / 2015$. 
Skjelsbaek, Inger (2001), "Sexual Violence and War: Mapping Out a Complex Relationship”, European Journal of International Relations, 7 (2): 211-237.

Smith, Andrea (2003), "Not an Indian Tradition: The Sexual Colonization of Native Peoples", Hypatia, 18 (2): 70-85.

Tharp, Julie (2014), "Erdrich's Crusade: Sexual Violence in The Round House", Studies in American Indian Literatures, 26 (3): 25-40.

Ulin, David L. (2012), "Review: Home by Toni Morrison Feels Distant", Los Angeles

Times, 06/05/2012. <http://www.latimes.com/entertainment/la-ca-toni-morri son-20120506-story.html>

Visser, Irene (2014), “Entanglements of Trauma: Relationality and Toni Morrison's Home”, Postcolonial Text, 9 (2): 1-21.

-(2016), "Fairy Tale and Trauma in Toni Morrison's Home", Melus, 41 (1): 148-164. Washington, Harriet A. (2006), Medical Apartheid: The Dark History of Medical Experimentation on Black Americans from Colonial Times to the Present, New York, Doubleday. 